\title{
THE INFLUENCE OF HEXACYANOFERRATE (II) POTASSIUM-FERRIC (III) AS A RADIONUCLIDE SORBENT FED AT DIFFERENT DOSES ON CLINICAL, HEMATOLOGICAL AND PHYSIOLOGICAL PARAMETERS IN RATS
}

\author{
E.B. MIRZOEV, V.O. KOBYALKO, N.N. ISAMOV (Jr.), O.A. GUBINA, \\ N.A. FROLOVA
}

All-Russian Research Institute of Radiology and Agroecology, Federal Agency of Scientific Organizations, 109 km, Kievskoe sh., Obninks, Kaluzhskaya Province, 249032 Russia, e-mail mirzoev.ed@yandex.ru Received June 19, 2014

\section{Abstract}

A problem to be overcome under radioactive pollution of the territory is how to produce animal products, particularly milk and meat, of due sanitary and hygienic quality. It is well known that agrotechnologies and agromelioration are not enough for decreasing transition of ${ }^{137} \mathrm{Cs}$ from fodder to milk and meat more than 2.0-2.5 times. However, sorbents such as ferrocene-containing preparations Ferrocene, Biphezh, boluses and briquettes of lickstones can be used. Officinal ferrocene and ferrocene- 2 are successfully being applied in livestock on the territories polluted with radionuclides. A substantiation of the optimal doses of fine ferrocene fed to animals necessitates the examination of possible toxicity of the preparation as far as it can sorb essential nutrients and metabolites when entering the gastrointestinal tract. The influence of hexacyanoferrate (II) potassiumferric (III), the fine blue odorless water-, alcohol- and ether-insolube powder with a particle diameter of $0.002 \mathrm{~mm}$, was investigated on 3 month aged Wistar line rats of $250 \pm 20 \mathrm{~g}$ weigh. A daily intake of the preparation with feed was $11.6,23.2$ and $32.4 \mathrm{mg} / \mathrm{kg}$ during 30 days of the experiment. We studied the hemoglobin, erythrocytes and leukocytes levels, morphological variants of leukocytes, content of SH-groups, blood serum proteins and their fractions, malonic dialdehyde level, catalase and superoxide dismutase activity in the peripheral blood, the DNA synthesis and reparation, metallotionein content in spleen lymphocytes, cellularity and weight of liver, kidney and spleen. Also appetite and reactivity of animals were examined. It was shown that the optimal daily dose of preparation is $11.6 \mathrm{mg} / \mathrm{kg}$. With the increase of the hexacyanoferrate (II) potassium-ferric (III) daily level up to 23.2 and $32.4 \mathrm{mg} / \mathrm{kg}$ the negative reactions were observed along with the development of defense and compensatory processes. Thus, in plasma of peripheral blood the increase of total protein content due to $\alpha-, \beta$ - and $\gamma$-globulin levels was shown with the simultaneous decrease in albumin level. In spleen lymphocytes the cells amount reduction in the organ, activation of the DNA synthesis and reparation processes were registered compared to control. The differences in clinical haematological and physilogical indices between experimental and control groups were not discovered. It is supposed, that the revealed changes can be due not only to essential elements deficiency caused by their sorption in a gastrointestinal tract, but also by the intake of ferrum.

Keywords: radionuclides, hexacyanoferrate (II) potassium-ferric (III), rat, blood plasma, protein, reparation synthesis of DNA.

Radioactive contamination of territories creates one of the major problems for the agricultural production, particularly how to produce safe and healthy animal products, particularly milk and meat, meeting the requirements of Russian sanitary legislation [1]. Agrotechnologies and agromelioration alone have been proven to be insufficient to decrease the transition of ${ }^{137} \mathrm{Cs}$ from the animal diet into milk and meat more than 2.0-2.5 times. On the other hand, sorbents, such as ferrocene-containing preparations Ferrocene, Biphezh, boluses and mineral salt blocks, are favorable to the production of products meeting the adopted guidelines [2-5].

Potassium iron(III) hexacyanoferrate(II) (ferrocene) entering in the cows' bodies in the doses of 6-24 mg/kg (3-12 g per 1 animal/day) with the diet reduced ${ }^{137} \mathrm{Cs}$ content in the foodstuffs and had no adverse effects on the health of the animals. An assessment of the clinical, physiological and hematological 
indices, content of metabolic hormones, macro- and microelements in the blood plasma detected no deviations from the control values [6-9]. An examination of veterinary-sanitary and sanitary-hygienic indices of milk produced from the cows which received ferrocene-containing preparations (FCP), revealed no differences relative to the control cows either. Toxicological experiments on rats showed that milk from those cows was safe and could be used without limitations [10].

Similar results were obtained on sheep, which received ferrocene in the dose of $50 \mathrm{mg} / \mathrm{kg}(2 \mathrm{~g}$ per 1 animal/day) for 120 days. To find out if iron could enter the tissues of organs, 3-4 days prior to the slaugther ${ }^{59} \mathrm{Fe}$-labelled ferrocene was included in the diet. As a result, ${ }^{59} \mathrm{Fe}$ only accumulated in the rib tissues in the amount of $0.22 \%$ of the administered dose [11].

An assessment of the efficiency of ferrocene-containing sorbents depending on their form and dispersity made it possible to select ferric ferrocyanide with particle sizes of $0.02-0.03 \mathrm{~mm}$, since this chemical was less efficient at higher dispersities (over $0.10 \mathrm{~mm}$ ) [12]. Currently officinal ferrocene and ferrocene-2 (a veterinary form of the sorbent) are successfully applied in cattle husbandry on the territories contaminated with radionuclides (Order of the Minister of Healthcare of the USSR № No.1253 dated December 25, 1978. Pharmacopoeial monograph № 42-2B13-91. Veterinary rules 13.73 .13 dated June 12, 1999). Hazard and toxicity classes of these chemicals are 4th and 5th, correspondingly.

It should be noted that the action of fine sorbents (particle sizes of less than 0.02 and $0.03 \mathrm{~mm}$ ) on the health of mammals has not been studied and its safe doses have not been determined.

A scientific justification of optimal doses of fine ferrocene in the food of animals involves investigation into possible toxicity of the chemical since when swallowed it can absorb essential nutrients and metabolites in the gastrointestinal tract.

The purpose of this work was to study the action of different doses ferrocene with the particle size of $0.002 \mathrm{~mm}$ on the physiological condition of rats.

Technique. The investigation, which was performed in a vivarium of the All-Russia Research Institute of Radiology and Agroecology, involved twenty 3month-old Wistar rats weighing $250 \pm 20 \mathrm{~g}$. Keeping, feeding and care were in accordance with the requirements of the Rules for Performance of Works with the Use of Experimental Animals (Order of the Ministry of Health and Social Development of Russia No.708n, August 23, 2010). The diet of the rats was standard (Laboratorkorm, Moscow) and they had unlimited access to water. The feed included cereals, fish meal, sunflower oil, vitamins and minerals. The proportion of main components in the feed was as follows: crude protein $-19 \%$, crude fat $-5 \%$, crude ash $-9 \%$, crude fiber $-4 \%$, calcium $-1.8 \%$, phosphorus $-1.1 \%$, vitamin $\mathrm{A}-5000 \mathrm{IU} / \mathrm{kg}$, vitamin $\mathrm{D}-500 \mathrm{IU} / \mathrm{kg}$, vitamin $\mathrm{E}-4.8 \mathrm{IU} / \mathrm{kg}$; humidity $-13.5 \%$.

The animals were split into four groups of 5 rats in each. Group I was the control. For 30 days, the rats from groups II, III and IV received $2.9 \mathrm{mg}$, $5.8 \mathrm{mg}$, and $8.1 \mathrm{mg}$ of ferrocene per 1 animal a day with their rations. The daily dose of the chemical for the animals in group II was $11.6 \mathrm{mg} / \mathrm{kg}$ of weight; in group III it was $23.2 \mathrm{mg} / \mathrm{kg}$; and in group IV it was $32.4 \mathrm{mg} / \mathrm{kg}$. It should be noted that per $1 \mathrm{~kg}$ of body weight, the daily doses of $2.9 \mathrm{mg}$ ferrocene for rats (the body weight is $250 \mathrm{~g}$ ) and $6.0 \mathrm{~g}$ for cows (the body weight is $500 \mathrm{~kg}$ ) are comparable. The experiment involved ferrocene (Milori blue) with the particle size of $0.002 \mathrm{~mm}$, which contained potassium iron(II) hexacyanoferrate(III) $\mathrm{KFe}\left[\mathrm{Fe}(\mathrm{CN})_{6}\right](5 \%)$ and hexacyanoferrate $\mathrm{Fe}\left[\mathrm{Fe}(\mathrm{CN})_{6}\right](95 \%)$. The chemical was a fine powder of dark-blue color, odorless, almost insoluble in water, alcohol, or ether. The samples of blood and organs were taken from rats on day 30 of the investigation under ether anesthesia. 
The action of ferrocene on the health of animals was assessed based of the following biochemical indices: hemoglobin, erythrocyte and leukocyte levels in the peripheral blood, leukocyte morphology [13], content of SH-groups, proteins and percentage of protein fractions in the blood plasma [13-15], malonic dialdehyde level (MDA), catalase (CAT) and superoxide dismutase (SOD) activity in the plasma and erythrocytes of the peripheral blood [16-18], DNA synthesis (general and reparative), and metallothioneins (MT) content in the lymphocytes of the spleen [19-21], cellularity and organ-weight indexes (liver, kidneys and spleen) [22]. Moreover, the general condition of rats, their appetite and response to external stimuli, as well as the functional status of gastrointestinal tract were taken into account.

Plasma of the peripheral blood and the lymphocytes of the spleen were taken using standard methods [13, 23]. The viability of lymphocytes was determined in the test with trypan blue.

The results were processed by the standard parametric statistics using the $t$-criterion of Student. The differences in the values were considered reliable at $\mathrm{p}<0.05$ [24].

Results. The levels of hemoglobin, erythrocytes and leukocytes in the peripheral blood of the rats from the experimental groups revealed no significant differences compared with the control group (Table 1). The trend towards the increased hemoglobin and erythrocytes levels was noted in the animals from group IV, which received ferrocene in the dose of $32.4 \mathrm{mg} / \mathrm{kg}$ with the diet. No significant differences in the leukocyte morphology, general condition of the animals, their appetite, response to external stimuli and the functional status of the gastrointestinal tract were revealed between the experimental and control group.

1. Hemoglobin, erythrocyte and leukocyte levels in the peripheral blood of Wistar rats receiving ferrocene with the particle size of $0.002 \mathrm{~mm}$ in different doses with the diet ( $M \pm m$, laboratory experiment)

\begin{tabular}{l|c|c|c}
\hline \multicolumn{1}{c|}{ Group } & Leukocytes, ths./mcl & Erythrocytes, mln/mcl & Hemoglobin, g/l \\
\hline I & $6.8 \pm 0.9$ & $10.0 \pm 0.9$ & $168.4 \pm 5.7$ \\
II & $5.9 \pm 1.1$ & $11.6 \pm 1.2$ & $164.9 \pm 6.4$ \\
III & $5.0 \pm 1.1$ & $9.6 \pm 0.8$ & $165.6 \pm 14.1$ \\
IV & $6.5 \pm 1.9$ & $12.5 \pm 1.3$ & $178.0 \pm 2.1$ \\
\multicolumn{2}{l}{ N o t e : Group descriptions see in "Technique» section. } & \\
\hline
\end{tabular}

Protein content in the peripheral blood plasma of the animals from the experimental groups was increasing (Table 2). The reliable differences compared with the control group were observed in group III rats, which received ferrocene in the dose of $23.2 \mathrm{mg} / \mathrm{kg}$. The analysis of the ratio between the protein fractions revealed a reduction in albumin: for the animals from groups III and IV, the values were lower than for the rats from group I by $32 \%(\mathrm{p}<0.05)$ and $37 \%$ $(\mathrm{p}<0.05)$ correspondingly, with a trend towards an increase in $\alpha-, \beta-$ and $\gamma-$ globulin counts in the blood plasma of the experimental animals and the albumin-globulin ratio definitely below the values in the control group.

Therefore, the increase in the content of total protein in the plasma of the peripheral blood of the experimental rats was due to $\alpha-, \beta$ - and $\gamma$-globulin fractions. The reduction in the albumin level in blood plasma and the albuminglobulin ratio may be indicative of adverse reactions in the bodies of animals from groups III and IV. In general, the increase in the total protein content in blood plasma due to globulin fractions concurrent with the reduction in the albumin content gives grounds to assume toxicosis in the animals by biochemical indices with no clinical signs of the disease (9). 
2. Percentage (\%) of protein and its fractions in the blood plasma of Wistar rats receiving ferrocene with the particle size of $0.002 \mathrm{~mm}$ in different doses with the diet $(M \pm m$, laboratory experiment)

\begin{tabular}{l|c|c|c|c|c|c}
\hline \multicolumn{1}{c|}{ Group } & $\begin{array}{l}\text { Total pro- } \\
\text { tein, } \mathrm{mg} / \mathrm{ml}\end{array}$ & Albumin & $\alpha$-Globulin & $\beta$-Globulin & $\gamma$-Globulin & $\begin{array}{l}\text { Albumin/glo- } \\
\text { bulins }\end{array}$ \\
\hline I & $73.9 \pm 5.2$ & $29.2 \pm 2.1$ & $19.2 \pm 3.9$ & $18.8 \pm 3.6$ & $35.5 \pm 4.1$ & $0.43 \pm 0.05$ \\
II & $82.2 \pm 5.3$ & $25.4 \pm 3.2$ & $23.9 \pm 4.3$ & $21.4 \pm 5.1$ & $41.4 \pm 3.3$ & $0.35 \pm 0.06$ \\
III & $118.7 \pm 14.0^{*}$ & $19.9 \pm 3.0^{*}$ & $24.4 \pm 1.8$ & $22.8 \pm 3.9$ & $40.3 \pm 3.1$ & $0.25 \pm 0.04^{*}$ \\
IV & $95.0 \pm 9.1$ & $18.3 \pm 3.1^{*}$ & $25.4 \pm 1.3$ & $19.0 \pm 2.8$ & $37.3 \pm 2.8$ & $0.23 \pm 0.05^{*}$ \\
N o t e : Group descriptions see in «Technique» section." \\
* Experiment to control differences are reliable at p < 0.05. \\
\hline
\end{tabular}

An assessment of indices characterizing free-radical lipid peroxidation (LPO) in the bodies of rats made it possible to identify the following specific features. MDA concentrations in plasma of the peripheral blood of the experimental animals did not differ from the control values (Table 3 ). It was possibly due to the activity of the antioxidant enzymes, which include SOD and CAT. SOD is well known to be a key enzyme of the antioxidant defense system and is found in all types of cells of mammals. The enzyme reacts with a superoxide anion radical with the formation of hydrogen peroxide thus preventing the reduction of $\mathrm{Fe}^{3+}$ to $\mathrm{Fe}^{2+}$. It should be noted that in reactions with hydrogen peroxide and hypochlorite, $\mathrm{Fe}^{2+}$ forms hydroxyl radicals $\left(\mathrm{HO}^{\circ}\right)$, which are reactive and cause damage to proteins, nucleic acids and lipids of cellular membranes. On the other hand, catalase (a heme enzyme) breaks down hydrogen peroxide into water and molecular oxygen [25-27].

3. Content of malonic dialdehyde (MDA), SH-groups and activity of superoxide dismutase (SOD) and catalase (CAT) in peripheral blood plasma of Wistar rats receiving ferrocene with the particle size of $0.002 \mathrm{~mm}$ in different doses with the diet $(M \pm m$, laboratory experiment)

\begin{tabular}{|c|c|c|c|c|}
\hline Group & $\mathrm{MDA}, \mathrm{nmol} / \mathrm{ml}$ & $\begin{array}{l}\text { Activity of } \\
\text { SOD, \% }\end{array}$ & $\begin{array}{l}\text { Activity of CAT, mcmol } \\
\mathrm{H}_{2} \mathrm{O}_{2} /(\mathrm{s} \cdot \mathrm{ml})\end{array}$ & $\begin{array}{l}\text { SH-groups, } \\
\mathrm{mol} / 10^{5} \mathrm{~g} \text { of protein }\end{array}$ \\
\hline I & $4.20 \pm 0.12$ & $32.60 \pm 2.19$ & $1.50 \pm 0.05$ & $0.72 \pm 0.08$ \\
\hline II & $4.14 \pm 0.03$ & $31.30 \pm 1.18$ & $1.60 \pm 0.01$ & $0.68 \pm 0.07$ \\
\hline III & $4.16 \pm 0.08$ & $35.14 \pm 2.50$ & $1.20 \pm 0.20$ & $0.36 \pm 0.05^{*}$ \\
\hline IV & $4.00 \pm 0.05$ & $43.30 \pm 2.60^{*}$ & $1.10 \pm 0.15$ & $0.32 \pm 0.04^{*}$ \\
\hline
\end{tabular}

The analysis of CAT activity in the peripheral blood plasma of the experimental rats revealed a trend towards a reduction in the values of this indicator (Table 3). By contrast, the SOD activity increased. Reliable differences relative to the control group were registered for the rats from group IV. CAT activity might depend on the amount of hydrogen peroxide, particularly the activity decreases when the amount is low and increases when it is high. On the other hand, formation of superoxide anion radicals activates SOD. Moreover, SOD contains $\mathrm{Cu}^{2+}$, $\mathrm{Zn}^{2+}$, and $\mathrm{Mg}^{2+}$ as catalytic centers, and catalytic centers of CAT contain $\mathrm{Fe}^{2+}$, therefore modification of their activity can be explained by the excess or deficit of these elements. The content of SH-groups of proteins decreased in the peripheral blood plasma of the animals, which received ferrocene with the diet (see Table 3). Reliable differences in the values relative to the control were registered in the rats from groups III and IV.

An assessment of free-radical LPO intensity in erythrocytes of the peripheral blood of the experimental rats revealed more pronounced changes (Table 4). Thus, with $52 \%$ in relation to the control $(\mathrm{p}<0.05)$, MDA content in the rats from groups III and IV was lower than in the animals from group I. The reduction in MDA content was obviously due to the activity of the antioxidant enzymes (SOD and CAT). Relative to the control group, the activity of SOD in 
the erythrocytes of the peripheral blood of rats from groups III and IV increased by $68.6 \%(\mathrm{p}<0.05)$ and $109.9 \%(\mathrm{p}<0.05)$ correspondingly, while CAT was $59.0 \%(\mathrm{p}<0.05)$ and $76.0 \%(\mathrm{p}<0.05)$ higher correspondingly.

The changes in the MDA content and the activity of SOD and CAT in erythrocytes of the peripheral blood of animals from groups III and IV might be indicative of the development of body's defense and compensatory responses.

4. Content of malonic dialdehyde (MDA) and activity of superoxide dismutase (SOD) and catalase (CAT) in peripheral blood erythrocytes in Wistar rats receiving ferrocene with the particle size of $0.002 \mathrm{~mm}$ in different doses with the $\operatorname{diet}(M \pm m$, laboratory experiment)

\begin{tabular}{l|c|c|c}
\hline \multicolumn{1}{c}{ Group } & MDA, pmol/cell & Activity of SOD, $\%$ & Activity of CAT, $\mathrm{pmol} \mathrm{H}_{2} \mathrm{O}_{2} /(\mathrm{s} \cdot$ cell $)$ \\
\hline I & $7.3 \pm 0.9$ & $11.8 \pm 1.0$ & $305.2 \pm 58.5$ \\
II & $6.0 \pm 0.3$ & $11.8 \pm 1.6$ & $317.3 \pm 44.0$ \\
III & $3.8 \pm 0.4^{*}$ & $19.9 \pm 1.5^{*}$ & $484.9 \pm 38.5^{*}$ \\
IV & $3.8 \pm 0.4^{*}$ & $24.7 \pm 2.7^{*}$ & $535.6 \pm 61.0^{*}$ \\
N o t e : Group descriptions see in $\ll$ Technique» section. & \\
* Experiment to control differences are reliable at $\mathrm{p}<0.05$. &
\end{tabular}

5. Functional status and viability of spleen lymphocytes in Wistar rats receiving ferrocene with the particle size of $0.002 \mathrm{~mm}$ with the diet $(M \pm m$, laboratory experiment)

\begin{tabular}{|c|c|c|c|c|}
\hline \multirow{2}{*}{ Group } & \multicolumn{2}{|c|}{ DNA synthesis, $\mathrm{imp} \cdot \mathrm{min}^{-1} \cdot(\mathrm{mln} \text { cell })^{-1}$} & \multirow{2}{*}{$\begin{array}{l}\text { Content of metal- } \\
\text { lothioneins, ng } / 10^{7} \text { cell }\end{array}$} & \multirow{2}{*}{ Cell viability, \% } \\
\hline & general & reparative & & \\
\hline I & $124.3 \pm 6.6$ & $71.2 \pm 4.5$ & $180.7 \pm 61.0$ & $95.2 \pm 1.3$ \\
\hline II & $103.0 \pm 7.5$ & $65.9 \pm 4.3$ & $156.6 \pm 33.8$ & $96.8 \pm 0.2$ \\
\hline III & $153.6 \pm 3.1^{*}$ & $86.8 \pm 6.5$ & $158.8 \pm 43.5$ & $95.8 \pm 0.8$ \\
\hline IV & $175.0 \pm 6.0^{*}$ & $106.5 \pm 7.4^{*}$ & $280.9 \pm 27.7^{*}$ & $96.1 \pm 0.5$ \\
\hline
\end{tabular}

The functional status of spleen lymphocytes in the rats was estimated by the MT content and DNA synthesis (general and reparative). MTs are low molecular weight proteins $(6-7 \mathrm{kDa})$ which bind heavy metal ions and act as a trap for free radicals $[28,29]$. In groups II and III, there was a trend towards a decrease in the content of MT in the spleen lymphocytes. On the other hand, for the animals from group IV, the value reliably increased by $55 \%$ (Table 5). Obviously the daily doses of ferrocene entering the rats' bodies in the amount of $32.4 \mathrm{mg} / \mathrm{kg}$ induced synthesis of MT in the cells. We assume that this increase in the MT amount in spleen lymphocytes was related to the formation of free radicals and indicative of the development of the adaptive defenses of the body.

The investigation into the synthesis of DNA in spleen lymphocytes revealed reliable increase in the value in groups III and IV by $24 \%$ and $41 \%$, correspondingly, with the intensification of DNA synthesis in the cells due to activation of reparative processes. The reliable differences as compared with the control were registered in the rats from group IV.

Therefore, the daily doses of ferrocene added to the diet in the amount of $23.2 \mathrm{mg} / \mathrm{kg}$ and $32.4 \mathrm{mg} / \mathrm{kg}$ led to changes in the functional status of spleen lymphocytes, with no viability indices deviating from the control values. The detected changes, namely the activation of the reparative synthesis of DNA, point to the development of compensatory processes in the cells.

The cell count in the spleen reliably decreased in the rats from groups III and IV by $31 \%$ and $29 \%$, correspondingly (Table 6), with the cellularity of the eliminative and detoxication organs (liver and kidneys) reliably similar to the control. The hepatic and renal cells are probably more resistant to toxic elements than splenocytes. Moreover, being a hematopoietic organ, the spleen maintains homeostasis of cell populations in the peripheral blood. The organ-weight indices (liver, kidney, spleen) revealed no essential deviations relative to the control 
(see Table 6). The comparative analysis of cellularity and organ-weight indices (namely the reduction in spleen lymphocyte count with no changes in the spleen weight index) suggested development of the negative processes in the body.

6. Cellularity and organ-weight index in Wistar rats receiving ferrocene with the particle size of $0.002 \mathrm{~mm}$ with the diet ( $M \pm m$, laboratory experiment)

\begin{tabular}{|c|c|c|c|}
\hline \multirow{2}{*}{ Group } & \multicolumn{3}{|c|}{ Organ } \\
\hline & liver & kidneys & spleen \\
\hline \multicolumn{4}{|c|}{ C e 11 u la rit $y$, cell/mg of tissue } \\
\hline I & $54,142 \pm 3,650$ & $129,201 \pm 7,971$ & $365,809 \pm 28,979$ \\
\hline II & $60,144 \pm 5,613$ & $130,680 \pm 9,179$ & $292,844 \pm 27,141$ \\
\hline III & $50,437 \pm 3,906$ & $129,428 \pm 5,898$ & $252,827 \pm 11,075^{*}$ \\
\hline IV & $59,565 \pm 3,473$ & $111,065 \pm 6,008$ & $261,201 \pm 23,949^{*}$ \\
\hline \multicolumn{4}{|c|}{ Organ-weight index, rel. units } \\
\hline I & $0.0288 \pm 0.0011$ & $0.0061 \pm 0.0001$ & $0.0036 \pm 0.0002$ \\
\hline II & $0.0272 \pm 0.0010$ & $0.0060 \pm 0.0001$ & $0.0036 \pm 0.0003$ \\
\hline III & $0.0289 \pm 0.0014$ & $0.0060 \pm 0.0002$ & $0.0037 \pm 0.0002$ \\
\hline IV & $0.0289 \pm 0.0005$ & $0.0063 \pm 0.0001$ & $0.0038 \pm 0.0002$ \\
\hline
\end{tabular}

Thus, for Wistar rats, the optimum daily dose of ferrocene with the particle size of $0.002 \mathrm{~mm}$ is $11.6 \mathrm{mg} / \mathrm{kg}$. Increased doses of the chemical in the diet (daily doses of $23.2 \mathrm{mg} / \mathrm{kg}$ and $32.4 \mathrm{mg} / \mathrm{kg}$ ) led to the development of defense and compensatory responses, with a number of adverse reactions in some cases. Thus, an increase in the total protein content in the blood plasma due to globulin fractions concurrent with the reduction in the albumin content points to toxicosis in the animals with no clinical signs of the disease. Ferrocene in the doses of $23.2 \mathrm{mg} / \mathrm{kg}$ and $32.4 \mathrm{mg} / \mathrm{kg}$ might bind a larger amount of macro- and microelements in the gastrointestinal tract, and this defines the response of the body. However, the reduction in the spleen cellularity is difficult to explain by their deficit. Ferrocene in the diet might facilitate the absorption of soluble salts of iron, which only show activity in high doses, in the gastrointestinal tract. This theory is supported by the tendency to the increase in the amount of hemoglobin and erythrocytes in the peripheral blood of the rats which received ferrocene in the daily dose of $32.4 \mathrm{mg} / \mathrm{kg}$ with their diet. With the decreased cellularity of the spleen, spleen lymphocytes demonstrated activation of the DNA synthesis and the intensity of reparative processes. There were no differences in the clinical, hematological, and physiological indices (general condition, appetite, responses to external stimuli and functional status of the gastrointestinal tract) between the experimental and control group of rats.

\section{R E F E R E N C E S}

1. Gigienicheskie trebovaniya bezopasnosti i pishchevoi tsennosti pishchevykh produktov. Sanitarno-epidemiologicheskie pravila i normativy SanPin 2.3.2.1078-01 [Food stuff hygienic safety and nutritive value. Sanitary and epidemiological rules and norms]. Moscow, 2002.

2. Radioekologicheskie aspekty zhivotnovodstva (posledstviya $i$ kontrmery posle katastrofy na Chernobyl'skoi AES) [Radiological and environmental aspects of livestock: consequences of Chernobyl accident and protective measures. R.G. Il'yazov (ed.)]. Gomel', 1996.

3. S a n zha rova N.I., S y so e va A.A., I s a mov N.N. (Jr.), A le ks a kh i n R.M., Kuznetsov V.K., Zhig a reva T.L. Rossiiskii khimicheskii zhurnal (ZHRKHO im. D.I. Mendeleeva), 2005, 49(3): 26-34.

4. I l'y a z o v R.G. Chernobyl'skaya katastrofa $i$ agrosfera: posledstviya $i$ kontrmery [Chernobyl disaster and agro sphere: consequences and protection]. Kazan', 2011.

5. Il'y a z o v R.G. Sel'skokhozyaistvennaya Biologiya [Agricultural Biology], 2006, 2: 3-17.

6. I 1 ' y a z o v R.G., A v e r i n V.S. Materialy nauchno-prakticheskoi konferentsii, posvyashchennoi 40-letiyu osnovaniya GNU VNIISKHRAE Rossel'khozakadenii "Problemy radiologii $i$ agroekologii» [Proc. Conf. «Challenges in radiology and agroecology». R.M. Aleksakhin (ed.)]. Obninsk, 2012: 200-207.

7. Il'y a z ov R.G. Materialy nauchno-prakticheskoi konferentsii, posvyashchennoi 40-letiyu osnovaniya GNU VNIISKHRAE Rossel'khozakadenii "Problemy radiologii $i$ agroekologii» 
[Proc. Conf. «Challenges in radiology and agroecology». R.M. Aleksakhin (ed.)]. Obninsk, 2012: 208-227.

8. Aleksakhin R.M., Ratnikov A.N., Vasil'ev A.V., Is a mov N.N., Krasnova E.T., M o rozov I.A., B u d a rk ov V.A. Vestnik RASKHN, 1999, 1: 15-17.

9. Hove K., Strand P., Salbu B., Oughton D., Astasheva N., Sobolev A., Vasiliev A., Ratnikov A., Aleksakhin R., Jigareva T., Averin V., Firsakova S., C rick M., Richards J.I. Use of caesium binders to reduce radiocesium contamination of milk and meat in Belarus, Russia and Ukraine. Proc. Int. Symp. «Environmental input of radioactive releases». IAEA, Vienna, 1995: 539-547.

10. Ratnikov A.N., Vasiliev A.V., Alexakhin R.M., Krasnova E.G., Paster nak A.D., Hovard B.J., Hove K., Starnd P. The use of hexacyanoferrates in different forms to reduce radiocaesium contamination of animal products in Russia. Sci. Total Environ., 1998, 223: 167-176.

11. Kalinin N.F., Mayakov E.A., Budarkov V.A., B orisov V.P., Vasilenk o I.Ya., T o ru b a ro v A.A., E 1 i z a rov a I.A. Sel'skokhozyaistvennaya Biologiya [Agricultural Biology], 1993, 4: 93-98.

12. B or is ov V.P., Popov B.A., S e lets kaya L.I., Be linskaya F.A., Kalyuzhnyi V.A., K a 1 i n i n N.F. Sanitariya i gigiena, 1989, 4: 19-20.

13. Metody veterinarnoi klinicheskoi laboratornoi diagnostiki [Laboratory clinical diagnostics in veterinary medicine. I.P. Kondrakhin (ed.)]. Moscow, 2004.

14. O rek hovich V.N. Sovremennye metody $v$ biokhimii [Methods of recent biochemistry]. Moscow, 1977.

15. Low ry O.H., Rosebrough N.J., Farr A.L., Rand a 11 R.J. Protein measurement with the Folin phenol reagent. J. Biol. Chem., 1951, 193: 265-275.

16. Go n chare n k o M.S., Lat in ov a A.M. Laboratornoe delo, 1985, 1: 60-61.

17. D u b i n in a E.E., S a l'n i kova L.A., Ef i mova L.F. Laboratornoe delo, 1983, 10 : 30-33.

18. Gyth L. A simple method for determination of serum catalase activity and revision of reference range. Clinica Chimica Acta, 1991, 196: 143-152.

19. Koterov A.N., Trebenok Z.A., Pushkareva N.B., Nikol'ski i A.V. Radiatsionnaya biologiya. Radioekologiya, 1998, 38(3): 426-430.

20. Shevchenko A.S., S i monova Z.A., S hevchenko T.S. Radiobiologiya, 1991, 31(1): 137-139.

21. E a t o n D.L., T o a l B.F. Evaluation of the Cd/hemoglobin affinity assay for the rapid determination of metallothionein in biological tissues. Toxicol. Appl. Pharmacol., 1982, 66: 134-142.

22. Trakhtenberg I.M., Sova R.E., Shteftel' V.O., Onikienko F.A. Problema normy $v$ toksikologii (sovremennye predstavleniya $i$ metodicheskie podkhody, osnovnye parametry $i$ konstanty) [Normal and changed toxicological status: recent understanding, methods of estimation, informative indexes and constants]. Moscow, 1991.

23. Praktikum po immunologii [Workshop on immunology. I.A. Kondrat'eva, V.D. Samuilov (eds.)]. Moscow, 2001.

24. L a k in G.F. Biometriya [Biometry]. Moscow, 1990.

25. Ra o P.S., Kalva S., Yerrmilli A., Mamidi S. Free radicals and tissue damage: role of antioxidants. Free Radicals and Antioxidations, 2011, 1(4): 2-7.

26. Valko M., Leibfritz D., Moncol J., Cronin M.T.D., Mazur M., Telser J. Free radicals and antioxidants in normal physiological functions and human disease. Int. J. Biochem. Cell Biol., 2007, 39(1): 44-84 (doi: 10.1016/j.biocel.2006.07.001)

27. Valko M., Rhodes C.J., Moncol J., Izakovic M., Mazur M.M. Free radicals, metals and antioxidants in oxidative stress-induced cancer. Chemico-Biological Interactions, 2006, 160(1): 1-40 (doi: 10.1016/j.cbi.2005.12.009).

28. K a n g Y.J. Metallotionein redox cycle and function. Exp. Biol. Med., 2006, 231: 1459-1467.

29. K a ri n M. Metallothioneins: proteins in search of function. Cell, 1985, 41: 9-10. 